\section{Monimuotoisessa työyhteisössä yhdenvertaisuus on yksilöllisyyttä}

Pitkänen, Pirkko, Keisala, Katja \& Niiranen, Vuokko (toim.) (2017). Tavoitteena sujuva arki. Kulttuurien välinen työ sosiaali- ja terveydenhuollon työyhteisöissä. Tampere University Press. 254 sivua.

KULTTUURINEN monimuotoisuus voi olla sosiaali- ja terveydenhuollon (sote) organisaatioille voimavara, jos niillä on valmiuksia hyödyntää eri taustoista tulevien työntekijöiden osaamista. Henkilöstön ja asiakaskunnan kansainvälistyessä työyhteisöissä tarvitaan kulttuurien välistä oppimista, organisaation rakenteiden päivittämistä ja uudenlaista johtamisosaamista. Usein itsestäänselvyyksinä pidettyjä toiminta-, vuorovaikutus- ja johtamistapoja on kyseenalaistettava ja uudistettava.

Tavoitteena sujuva arki -teos pohjautuu Tampereen yliopistossa ja Itä-Suomen yliopistossa vuosina 2013-2017 toteutettuun MULTI-TRAIN-tutkimukseen. Siinä pyrittiin ratkomaan kulttuurien välisen työn ongelmia sotealan työyhteisöissä ja tuottamaan käytännönläheistä tietoa siitä, millaista muutosta kulttuurien välisen työn onnistumiseksi tarvitaan. Tutkimus toteutettiin yhdessä viiden sote-alan organisaation kanssa. Kukin osatutkimus esitellään teoksessa omana lukunaan. Kirjoittajia on kymmenkunta.

\section{HILJAINEN TIETO ESIIN}

Toimintatutkimuksen vahvuus on siinä, että ongelmien tunnistamisen ohella voidaan toimia niiden korjaamiseksi. Tutkijat muistuttavatkin, että vain rakenteellisilla uudistuksilla saadaan aikaan pysyviä muutoksia. MULTITRAIN-tutkimuksessa kehittäminen kohdistui käytäntöihin, jotka sujuvoittavat työyhteisöjen arkea monikulttuurisissa sote-alan organisaatioissa.

Tutkimukseen osallistuneissa työyhteisöissä oli sekä yksityisen että julkisen sektorin organisaatioita eri puolilta Suomea. Kaikissa niissä monikulttuurisuus oli jo arkea, mutta moninaisuus näyttäytyi valitettavan usein ongelmina.

Kitkaa syntyy usein silloin, kun toimintatavat ovat enemmistön määrittämiä. Heille ne näyttäytyvät kyseenalaistamattomina itsestäänselvyyksinä, mutta erilaisista kulttuuritaustoista tuleville käytänteet ovat vieraita. Toimintatutkimuksessa pureuduttiin ajattelu- ja toimintamalleihin, jotka ohjaavat työyhteisöjen käytäntöjä. Hiljainen tieto on harvoin keskustelun ja arvioinnin kohteena. Sen tunnistaminen ja näkyväksi tekeminen ovat kuitenkin edellytyksenä kulttuurien väliselle vuorovaikutukselle ja toiminnan kehittämiselle niin, että se vastaa monimuotoistuvan organisaation vaatimuksia.

Teoksessa esitellään monenlaisia käytännön tapoja edistää työ-

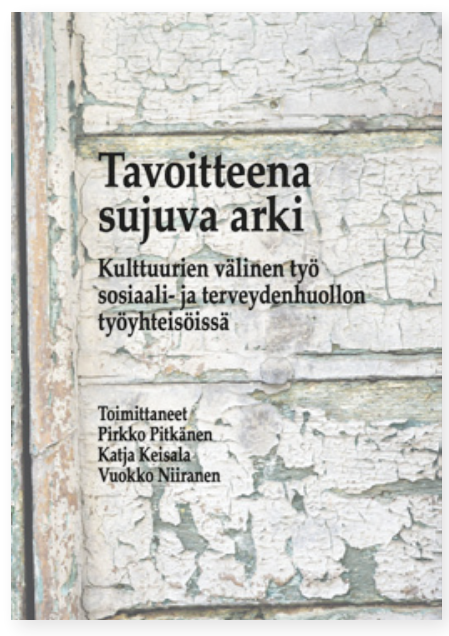

yhteisöjen valmiuksia kulttuurien välisessä työssä. Tutkimuksen kohteena olleissa työyhteisöissä järjestettiin koulutuksia ja työpajoja eri teemoista sekä kehitettiin muun muassa perehdytyskäytäntöjä ja tapoja kielen oppimisen tukemiseen.

\section{JOKAISTA TUETAAN}

\section{OSALLISUUTEEN}

Yksi Tavoitteena sujuva arki -kirjan tärkeitä teemoja on yhdenvertaisuus. Laissa 'yhdenvertaisuus' viittaa ennen muuta yhdenvertaiseen lopputulokseen, mutta työyhteisöjen arjessa oikeudenmukaisena pidetään yleensä sitä, että kaikilla työntekijöillä on taustastaan riippumatta samat oikeudet ja velvollisuudet. Mikäli lähtökohtana on suomalaisen työntekijän standardi, eikä eri taustoista olevien työntekijöiden edellytyksiä oteta huomioon täysimääräisesti, saattaa syntyä ongelmia. 
KEHITTÄMISEST $\ddot{A}$ TINGIT $\ddot{A} \ddot{A N}$,

KUN SIIHEN PIT ÄISI ERITYISESTI

PANOSTAA.

Mikäli taas kaikki yhteisön jäsenet taustoineen hyväksytään yhdenvertaisina, voidaan puhua aidosti monikulttuurisesta ja -arvoisesta työyhteisöstä, jossa erilaisuus tunnistetaan ja sitä arvostetaan. Yhdenvertaisessa työyhteisössä otetaan huomioon kunkin taustat ja valmiudet, ja heikossa asemassa olevia tuetaan tarvittaessa. Yhdenvertaisuus kytkeytyy kysymykseen työyhteisöön integroitumisesta. Tukitoimilla edistetään kaikkien pääsyä työyhteisön täysivaltaisiksi jäseniksi ja varmistetaan, että jokainen onnistuu ja viihtyy työssään.

Moniarvoisessa, yhdenvertaisessa työyhteisössä vallitsee kaksisuuntaisen oppimisen ilmapiiri. Tulokas yksin ei ole vastuussa siitä, että oppii työyhteisön käytännöt ja sopeutuu niihin, vaan koko työyhteisö pyrkii hyödyntämään uuden työntekijän osaamista ja oppimista. Näin kunkin valmiuksia ja asiantuntemusta hyödynnetään maksimaalisesti.

\section{KEHITTÄMISTOIMIA ORGANISAATION KAIKILLE TASOILLE}

Kulttuurien välinen työ ja vuorovaikutus vaativat vaivaa, voimavaroja ja aikaa. Kirjan viesti on, että kulttuurisen työn käytännöt muuttuvat vain, jos toimintaa kehitetään järjestelmällisesti ja organisaation kaikilla tasolla. Niin työntekijöiden kuin johdonkin on sitouduttava muutokseen.

Kulttuurien välisen vuorovaikutuksen valmiuksia voidaan lisätä kouluttamalla työntekijöitä, mutta lisäksi on kehitettävä ja juurrutettava työyhteisötason rakenteita ja käytäntöjä. Monimuotoistumisen vaatimiin kehittämistoimiin on myös kiinnitettävä huomiota strategioissa ja johtamiskäytännöissä, kuten resursseja ja henkilöstöpolitiikkaa koskevissa päätöksissä.

Kehittäminen kuitenkin kannattaa, sillä se lisää työviihtyvyyttä ja tuloksellisuutta. MULTITRAIN-tutkimus osoitti, että koulutusten ja kehittämistoimien myötä henkilöstön valmiudet kulttuurien väliseen vuorovaikutukseen lisääntyivät, vakiintuneita tottumuksia kyettiin muuttamaan, ja ulkomaalaistaustaisten työntekijöiden tarpeisiin, osaamiseen ja integraatioon ryhdyttiin kiinnittämään enemmän huomioita. Parhaimmillaan kehittäminen onnistuttiin nivomaan organisaation johtamiskäytäntöihin ja muihin ohjaaviin periaatteisiin, mikä mahdollisti muutosten toteuttamisen käytännössä.

Uusien käytäntöjen kehittämisestä kuitenkin helposti tingitään, kun organisaatioiden sisäiset ja ulkoiset muutospaineet vaikuttavat työyhteisöihin, ja kehittämistyön tarve pikemminkin kasvaa kuin vähenee.

\section{KEHITTÄMINEN VAATII RESURSSEJA}

Monimuotoisuutta koskevan osaamisen tarve kasvaa sote-alalla jatkuvasti. Tavoitteena sujuva arki sopiikin kaikille työyhteisöjen kehittämisen parissa toimiville. Kirja on selkeä ja kiinnostava kattaus työyhteisöjen monimuotoisuuden ja kulttuurien välisen työn tematiikasta ja aihetta koskevasta käsitteistä. Useat teoksen opit lienevät sovellettavissa muillakin aloilla. Samalla teos on oiva esitys toimintatutkimuksesta ja sen soveltamismahdollisuuksista.

Monikulttuurisuuden saattaminen voimavaraksi sote-alalle vaatii suunnitelmallista, resursoitua kehittämistä. Parhaimmat valmiudet toiminnan kehittämiseen näyttävät olevan yksityisellä puolella. Teoksessa ei kuitenkaan vertailla eri sektoreita vaan keskitytään itse asiaan: monikulttuurisen toimintaympäristön kehittämiseen työn, työntekijöiden ja työyhteisön näkökulmasta.

\section{SANNA PARRUKOSKI}

VTM, suunnittelija Vantaan kaupunki 